\title{
RACIAL RESPONSIBILITY REVISITED
}

\author{
Robert S. Taylor
}

\begin{abstract}
A common claim in the philosophy-of-race literature is that the unearned benefits of whiteness can by themselves burden their recipients with special antiracist obligations, that is, that these benefits can impose duties unilaterally, without the mediation of their recipients' wills, and that these duties go beyond our general antiracist duties, which derive from our common liberal-democratic citizenship and shared humanity. I will argue against this claim, though I acknowledge that there may be duties that follow from these benefits when they are combined with the affirmation or assertion of, assent to, or even mere acquiescence in white identity. Without such ratification, however, there will be no basis for either special white duties or a distinctively white guilt.
\end{abstract}

\begin{abstract}
re whites under any special duties solely because they enjoy certain "wages of whiteness"? ${ }^{1}$ No, I shall argue, although there may well be duties that follow from these wages when they are combined with the affirmation or assertion of, assent to, or even mere acquiescence in white identity. Absent such affirmation, however, there will be no basis for either special white duties or a distinctively white guilt.

These claims are contrary to much if not most of the existing philosophy-ofrace literature. Amy Gutmann, for instance, argues that whites are under special antiracist duties precisely because of the unfair benefits their race has brought them:
\end{abstract}

White Americans ... have a special obligation to fight racial injustice so as to decrease the likelihood that we will be the beneficiaries of unfair advantages that stem, for example, from the racial stereotyping of social offices and other forms of institutionalized injustices that unfairly disadvantage blacks. . . . Those of us who have unfairly benefited in the past, or will unfairly benefit in the future if we do not act to change things, have special obligations . . . not because we asked to be unfairly advantaged but because we have been and are unfairly advantaged. Because being white has been a source of unfair 
benefits in this country, fairness generates special obligations that are color conscious.... The special obligation of those who have benefited from racial injustice is to help undo the wrongs that perpetuate racial injustice. ${ }^{2}$

Similar sentiments are expressed by Charles Mills, but in a passage addressed to American Jews:

Doors have been opened for you that were closed to nonwhites. Whatever your personal feelings and political views, you are objectively socially advantaged by your racial characterization. Your moral responsibility now, as privileged members of society-indeed, the moral responsibility of all whites of goodwill -is to throw your political and organizational weight behind the opening of these doors to everyone. ${ }^{3}$

Such statements are far from unusual and can in fact be found throughout the scholarly literature. ${ }^{4}$

These and similar claims can be boiled down to the following thesis: the unearned benefits of whiteness can by themselves burden their recipients with special antiracist obligations. By "by themselves," I mean that these undeserved benefits impose obligations regardless of whether, for example, whites affirm their white identity, discriminate against minorities, and so on. In short, the duties are not mediated in any way by their wills, by their choices: as Gutmann succinctly puts the matter, whites are so burdened "not because we asked to be unfairly advantaged but because we have been and are unfairly advantaged." By "special," I mean obligations beyond those that whites are already under due to, say, a shared humanity or a shared liberal-democratic citizenship —and these general antiracist duties may be extremely demanding, even if we set aside those additional duties that whites allegedly bear "as privileged members of society." 6

As I noted at the very beginning, my purpose here is to challenge this commonly endorsed thesis - a challenge that will no doubt occasion some controversy, to put it mildly. Given this, and given the likelihood that I will be misunderstood, I should pause and reveal certain background beliefs and assumptions that I am working with, some of which I have already alluded to:

1. I recognize and endorse antiracist duties based upon our common humanity, understood in a Kantian way: in order to respect the free moral agency of others in a positive and not just a negative fashion, we must act to enable their agency by doing our part to remove obstacles to it, for example, those of racial discrimination and exclusion. We appropriately feel shame or guilt when we fail and/or humanity fails to discharge these duties.

2. I also recognize and endorse antiracist duties based on our common citizenship in a liberal-democratic society: in order to respect the political agency of others in a positive and not just a negative fashion, we must act to enable their agency by doing our part to bring about conditions of political equality, including fair equality of opportunity for all races in 
access to the ballot, holding public office, and otherwise influencing the political process. ${ }^{7}$ We appropriately feel shame or guilt when we fail and/ or our fellow citizens fail to discharge these duties.

3 . These antiracist duties might require that we support policies ranging from color blindness (i.e., racial neutrality) on one end of the spectrum to hate-speech laws, affirmative action, and racial reparations on the other. For the purposes of this paper, though, I remain agnostic regarding precisely what these duties entail.

As these remarks will hopefully indicate, my objection is not to the idea that we are under general antiracist duties and that these duties may be exceptionally demanding. Rather, my objection is to the far narrower idea that whites are under special antiracist duties due merely to the fact that they enjoy white privilege, that is, the undeserved benefits of whiteness.

I will begin my argument by re-examining the Speech of the Laws in Plato's Crito, showing how its demands for obedience are conditional not simply on the provision of (unearned) benefits to Socrates but also on the engagement of Socrates's will by means of opportunities for both voice and exit, with such engagement moderating the Laws' infamous authoritarianism and paternalism. With this as prologue, I then survey the absurd implications of the idea that recipients of unearned benefits can, merely on the basis of such benefits, be under special obligations. I next apply lessons from this reductio ad absurdum to the commonly endorsed thesis described earlier, responding to two powerful objections to this application in the course of doing so. Finally, I conclude the paper by recapping its arguments, showing how they call into question the widespread belief that whites should feel a special kind of guilt whether or not they affirm their white identity, and maintaining that the surest path to racial justice is on the ground, not of the superficial things that divide us, but of the deep things that unite us, namely our common liberal-democratic citizenship and humanity.

\section{THE ARGUMENTS FROM BENEFIT AND WILL IN CRITO'S SPEECH OF THE LAWS}

The Speech of the Athenian Laws in Plato's Crito is notorious for its authoritarianism and paternalism, at least in the eyes of its many critics, who interpret the Laws' speech as demanding an "absolute submission" (George Grote) and a "blind obedience" (Jacqueline de Romilly). ${ }^{8}$ Other scholars, however, have presented a more liberal reading, emphasizing the opportunities the Laws provide for the exercise of both voice (Richard Kraut) and exit (Jennet Kirkpatrick). ${ }^{9}$ The focused interpretation I shall offer here leans more toward the latter, more liberal reading, without endorsing Kraut's controversial claim that the Crito backs justified disobedience, which has been widely criticized..$^{10}$ My more specific purpose, 
however, will be to show the way that the Laws' demand for obedience from Socrates, on the grounds that they have benefitted him like good parents over a lifetime, is in fact made conditional on the engagement of Socrates's will by way of both voice (e.g., opportunities to persuade legislators and jurymen) and exit (e.g., opportunities to leave Athens, both before and after his trial [exile]). Athens is not Sparta, in short, and as harsh as the Athenian Laws may sound to modern ears, they do not maintain that obedience follows from delivered benefits alone, but also from Socrates's implicit consent to these Laws as evidenced by his speech and continued residence.

The most authoritarian and paternalistic passages in the Speech of the Laws can be found in what I shall call the Argument from Benefit. The Laws remind Socrates of their intimate role in his birth, upbringing, and education, benefits that he could not have earned in any meaningful way, summing up by asking: "Since you have been born and brought up and educated [by us], can you deny . . . that you were our child and slave, both you and your ancestors?"11 The Laws then elaborate upon this argument, claiming that Socrates must "patiently submit to any punishment that [they] impose, whether it be flogging or imprisonment," for reasons related to but even more compelling than those that require him to submit to correction by his father or master.

At this most illiberal point in their Speech, however, the Laws suddenly introduce a novel element into the argument, one apparently so important they repeat it three times, with the third iteration being the most revealing one: "Although we set a choice before [Socrates] and do not issue savage commands, giving him the choice of either persuading us or doing what we say, he's actually doing neither." 2 This recurring "persuade or obey" language suggests that the Laws themselves recognize that the Argument from Benefit is unlikely to persuade on its own, being too peremptory and imperious in both tone and content, so they emphasize their reasonableness, their willingness to listen to counterarguments. Such willingness was, of course, built into the political and judicial practices of Athens: specifically, its democratic assembly and juries and its numerous forums for free discussion, including the very agora where Socrates spent so much time as a "stinging fly," trying to rouse his fellow citizens to improve their souls. ${ }^{13}$ Unlike the "savage commands" of a Sparta, the Laws of Athens permitted-even expected - citizens to speak out on public matters and participate in politics; they engaged the wills of citizens by diverse opportunities for political voice, be they in the Assembly, the Council of the Five Hundred (on which Socrates served), the Agora, or before a jury of one's peers. ${ }^{14}$ Such engagement of the citizenry by yielding space for their political agency tempers the authoritarian paternalism of the Argument from Benefit; it gives Athenians like Socrates the right to speak and vote against certain laws (or interpretations of laws) and thus strengthens the case that they ultimately owe the Laws obedience. Call this the Argument from Will (Voice), which both qualifies and reinforces the Argument from Benefit. 
But the Laws of Athens go further than this, introducing another voluntaristic element into their overall argument for obedience, as several scholars have emphasized. ${ }^{15}$ The Laws point out that Socrates has resided continuously in Athens, rarely traveled abroad (or for that matter even left the city apart from one festival and a few military expeditions), has borne children there, and finally "preferred death ... to banishment," as evidenced by him proposing the punishment of "free dining in the Prytaneum" like an Olympic victor rather than exile at his trial. ${ }^{16}$ Little could be inferred from this were it not the case, as the Laws note, that "any Athenian, on attaining to manhood and seeing for himself the political organization of the State and us its Laws, is permitted, if he is not satisfied with us, to take his property and go away wherever he likes ... to one of our colonies ... or to emigrate to any other country." ${ }^{17}$ The exit costs, in other words, were low: there was no legal ban on emigration, one could take one's property and family along, and there were many Greek-speaking destinations, including Athens's own colonies. The Laws therefore take Socrates's constant presence to be a strong sign of consent to Athenian laws and institutions-tacit consent, to be sure, but given that Socrates was 70 at the time and had had innumerable (feasible) opportunities to leave, staying put spoke volumes. Call this the Argument from Will (Exit), which once again qualifies as well as reinforces the Argument from Benefit, strengthening the Laws' case that Socrates owes obedience.

In short, the apparent authoritarian paternalism of the Argument from Benefit is tempered by the two Arguments from Will: Benefit persuasively imposes an obligation of obedience only in the presence of Will, that is, only with the implied consent that takes forms both collective (exercising voice as a member of a demos empowered through public deliberation and political participation) and individual (continuously refusing to exit though permitted and enabled to do so). I highlighted "persuasively" to emphasize that the conditioning of Benefit on Will here is implicit, not explicit, in the Speech's rhetorical structure: the Laws keep adding voluntaristic elements as they progress through their speech, apparently aware that without them, they will fail to persuade their audience (ostensibly Socrates, but really Crito himself), who are, after all, citizens of a free city. The "savage commands" of an unfree city, by contrast, would depend upon the Argument from Benefit alone, permitting neither voice nor exit and therefore not engaging their citizens' wills in any meaningful way-like the Spartan or Cretan regimes for which Socrates expressed admiration. ${ }^{18}$ Such an argument might persuade a Spartan or Cretan, but surely not an Athenian ... or a citizen of any other free society, one would hope.

A less antique example may be helpful here. Consider the modern Sparta of East Germany, a regime that allowed neither exit nor voice-not even free choice of occupation-and so failed to engage its citizens' wills in any significant way. Would a doctor, selected and trained by the East German state, have an obligation to serve the East German regime merely on the grounds that they benefitted from 
its training and employment (including special privileges attached to both)? Would they do wrong by escaping to the West? ${ }^{19}$ Contrast this example with, say, Botswana, which allows emigration, free speech, political participation, and free choice of occupation. State provision of a medical education there might impose ethical if not legal obligations to remain and discharge one's debt to society. ${ }^{20}$ I would say that whatever one may think of the Botswana example, the case for special obligations in the East German example is weak; the Argument from Benefit alone bears little weight, and this will have consequences for moral claims relying on it. ${ }^{21}$

\section{THE ARGUMENT FROM BENEFIT: A REDUCTIO}

My deployment of the Crito's Arguments from Benefit and Will is meant to be exemplary, not dispositive: as canonical arguments about obligation (its sources and limits), they have a great deal of interest to us, but they raise as many questions as they answer and therefore cannot replace an independent examination. One question they raise is the following: Even if, consistent with my interpretation, the Arguments from Will strengthen but qualify the Argument from Benefit, might the latter still be able to stand on its own? Even I admitted that the Argument from Benefit might by itself be persuasive to a Spartan or Cretan — but might it also persuade a wider audience? I think it will prove useful at this point to think through the implications of a stand-alone Argument from Benefit as a way of trying to answer these questions.

Suppose it were the case that receipt of benefits imposed obligations, regardless of whether the will of the recipient was engaged in any way. This would mean, for example, that if I went out of my way to be friendly and helpful, beyond what normal politeness demands and what could be understood as our due, I would thereby impose obligations of some kind on the recipients. If I were similarly to beautify my front yard (say, by planting colorful flowers), beyond what neighborhood covenants and other mutually-agreed-upon rules required, I would put those who enjoyed my work under duties of some description. If, as a professor, I offered lectures of such extraordinary quality that they far surpassed anything that was contractually required, I would indebt my students. If, as a voter, I invested enormous effort in learning about issues and candidates, beyond what we would generally agree to be civic duty, I would place my fellow citizens in my debt, as they would benefit from my highly informed choices. If, as a citizen, I committed the great majority of my free time to organizing civic movements for beneficial social reform, I would once again put my fellow citizens under obligation to me. If, as an inventor, I tenaciously pursued an innovation that, once achieved, would yield social benefits that greatly exceeded any returns I might get (via patents, etc.), I would again obligate the beneficiaries to that extent.

A moment's reflection about these examples (and similar ones that my readers themselves can no doubt supply, ad infinitum) should reveal the following truth 
about any healthy society: in it, such benefit provision is ubiquitous. One of the many outstanding advantages of living in society is that we thereby become beneficiaries of all these supererogatory efforts, that is, acts going beyond what natural, civic, or contractual duties require. (I will say more about the sources of these duties below.) I think it would be uncontroversial to say that we generally admire such efforts, think well of those who engage in them, and are often inspired by them to act in similarly pro-social ways.

The Argument from Benefit, though, goes considerably further than this: it claims that the benefits generated by such efforts obligate their recipients simpliciter. If true, then the ubiquity of such benefits directly implies the ubiquity of the corresponding obligations. In any healthy society, therefore, we are apparently trapped in a dense thicket of duties not in any way of our own making. Insofar as there is any room left for our agency, it is a reactive sort involving balancing and seeking the means to live up to these manifold unchosen moral obligations, which fill up the space of our lives. If this argument is right, then we are practically hogtied by the binding benefits of supererogation.

This strikes me-and, I hope, the reader-as a reductio ad absurdum of the Argument from Benefit. I recognize, however, that for a certain kind of communitarian thinker, it simply describes our moral world. Michael Sandel, for example, contends that our moral agency is "not voluntarist but cognitive," focused on identifying, validating, and balancing those diverse claims upon us that follow ineluctably from our social embeddedness, which keeps us "awash with possible purposes and ends, all impinging indiscriminately on [our] identity, threatening always to engulf it."22 But this vision of our moral world chases agency into the interstices of our innumerable unchosen moral obligations; to continue with Sandel's metaphor, we become like the survivors of a shipwreck, struggling to stay afloat in an uncontrollable sea, trying to keep our heads above water by anticipating incoming waves. Surely we can acknowledge the key roles of social embeddedness and moral luck in our lives without acceding to Sandel's tragic vision. If, as I have maintained, the stand-alone Argument from Benefit has intolerable implications, then benefits cannot unilaterally impose duties; rather, they can only impose duties bilaterally, with the will playing some minimal supplementary role, at least, by means of affirmation, acceptance, acquiescence, and so on.

Perhaps surprisingly, I, too, think that our lives are thick with moral obligations; unlike the communitarians, however, I believe all these obligations are, at least in part, voluntaristic in origin. Consider, for example, the natural duties mentioned earlier. As I hinted in the introduction, I am a Kantian and, like many other Kantians, understand him in a voluntaristic way: Kant's moral theory "elevates all human beings to something like the status of divine legislators, dictating universally valid principles through the exercise of their rational wills. ${ }^{\prime 23}$ This is the source of the general moral duties that follow from our humanity. Civic duties, on 
the other hand, I see as following from (at least) three sources: humanity, benefit, and will. Roughly, humanity requires a liberal-democratic regime (see Kant's defense of liberal republicanism in his political works) that benefits its citizens in a variety of ways and thereby binds them to the polity, but conditionally so, only insofar as rights to public deliberation, democratic participation, and emigration are respected. My interpretation of the Crito is consistent with such a view of the sources of civic duties - perhaps anachronistically so, I admit. Finally, as for contractual duties, or consensual duties more broadly, these are more obviously voluntaristic in origin, and they account for the lion's share of the duties in our lives. These special obligations flow from our decisions to enter relationships with spouses, friends, co-workers, mentors and mentees, fellow parishioners and partisans, and so on. We realize our agency precisely by choice of projects, relationships, and the obligations associated with them. Consequently, the real problem with the communitarian vision is not its claim about the thickness of our obligations but rather their purported source. The will must always play at least a minimal role.

This sketch of my own comprehensive moral beliefs is, once again, meant to be exemplary rather than dispositive. As the earlier reductio was intended to show, the Argument from Benefit cannot stand on its own; it must be supplemented to one degree or another - or even replaced - by an Argument from Will. My own moral beliefs are simply one example among sundry others that meet this fairly weak requirement. Weak as it may be, though, it will prove too much for the thesis that is the focus of this paper, and to which I now return.

\section{AN APPLICATION TO THE WAGES-OF-WHITENESS THESIS}

To refresh readers' memories, I shall repeat the thesis in question: the unearned benefits of whiteness can by themselves burden their recipients with special antiracist obligations. As one can see, however, this thesis is simply an application of the stand-alone Argument from Benefit to one particular class of undeserved benefits, namely, those that are associated with whiteness, and I showed this Argument to have absurd implications. Benefits cannot unilaterally impose duties; rather, they can only impose duties bilaterally, with the will playing at least some minimal supplementary role by way of affirmation, acceptance, acquiescence, and so forth. If the will cannot be implicated in any way, then we face the same problem revealed by the reductio: our agency is once again relegated to the interstices of our proliferating unchosen moral obligations, as we shall see. Thesis advocates like Gutmann have emphasized, however, that our wills have no bearing at all on these special antiracist duties - and how could they, given that neither voice (from refusal of particular unearned benefits to total renunciation of white wages) nor exit (Where would whites go to escape these wages?) is even possible due to white privilege's unavoidably structural character? ${ }^{24}$ Unearned benefits of 
whiteness therefore implicate the will no more than East German medical training did, and similarly impose no special duties. Unless this particular class of unearned benefits has special characteristics that insulate the thesis from the force of the reductio - a possibility to which I shall return below-it is simply a nonstarter.

Having said this, many if not most whites might still be under special antiracist obligations precisely because their wills have been implicated in some meaningful manner. What forms might such will implication take? Consider the following four examples of ratification of white identity, in descending order of will implication:

1. Affirmation: public commitment by white supremacists/nationalists to their white identity and to the history, politics, and policies of white supremacy/nationalism.

2. Assertion: discrimination on the grounds of race (in choice of co-workers, friends, spouses, etc.) due to conscious white identity and/or hostility to racial minorities.

3. Acceptance: discrimination on the basis of race (in choice of co-workers, friends, spouses, etc.) simply due to greater comfort with those who share one's (white) race. ${ }^{25}$

4. Acquiescence: accepting a job when (i) the hiring committee was deciding between you (a white) and an equally qualified racial minority, and

(ii) the deciding vote in your favor was cast by a committee member who publicly stated that his reasons were racial.

As these examples indicate, rejecting the wages-of-whiteness thesis is far from being an assertion of white racial innocence or some sort of bad-faith absolution of whites with troubled consciences. I emphasize this point because one reason that readers might hesitate to reject the thesis is the not-unreasonable worry that doing so might be inconsistent with their other considered convictions on such matters. It is not: rejecting the thesis is entirely consistent with the idea that many - even most - whites are under special antiracist duties. Of course, this conclusion might raise something like the opposite concern: if the thesis and the alternative to it that I am sketching here are (close to being) extensionally equivalent, what is really at stake in this debate? But there is all the difference in the world between saying (1) many if not most whites are under special antiracist duties due to actions they have taken, and (2) all whites are under such duties due merely to their race and those benefits it brings. The former is consistent with our agency; the latter makes a mockery of it, as the reductio demonstrates and as I shall describe in greater detail below.

Let us return for a moment to the fourth example above (Acquiescence). I said earlier that the refusal of specific unearned benefits was impossible due to the inescapably structural nature of white privilege, but Acquiescence is the exception that proves the rule and is thus worth examining more carefully. Acquiescence has 
two especially salient features: (1) a publicly known illicit intent behind the benefit (viz., to provide white wages), and (2) an ability to refuse that benefit. Given that both of these features are present, the will of the white who accepts the benefit is clearly implicated: he consciously decides to agree to a job offer whose origin he knows to be corrupt. One can readily imagine situations where (1) will be present but not (2). Suppose, for instance, that the Ku Klux Klan adopts a vital, heavily trafficked road in a largely white community, paying for its beautification with the public intent of offering white wages to the inhabitants. ${ }^{26}$ If avoiding the road is extremely difficult (requiring moving from the community, say), then white residents might not be in a good position to refuse the benefit; accordingly, we would say that their wills are either weakly implicated or not implicated at all. Whether such situations are common is difficult to say, though I would think not. By contrast, situations where (2) is present but not (1) are undoubtedly frequent, and help to explain why the literature deems white privilege to be unavoidably structural. Racists on hiring committees rarely publicly announce the (genuine) reason for their votes, especially in a manner that would be accessible to a job candidate. More generally, whites are continually receiving benefits that could be refused but that, for all they know, may be tainted by racist motivations: How can whites be sure that when they are given a job offer, nice treatment in a shop or at the DMV, a warm reception to a romantic overture, and so on, they are not being benefitted (in whole or in part) for illicit racial reasons? Asymmetric information insulates white beneficiaries from will implication in such cases, but does it really insulate them from special moral responsibility, that is, responsibility beyond that which they bear as human beings and citizens? This brings us to the first objection to my critique of the thesis.

\section{Objection 1: Wider White Responsibility}

Sharon Krause has argued in her recent book Freedom Beyond Sovereignty that the kind of agency model I have been using throughout this paper is too narrow, mainly because it is too reliant on will implication: "Although the mark of agency is the manifestation of the individual's identity in her deeds, identity is not reducible to the will, and consequently agency sometimes exceeds or counteracts the individual's intentions." ${ }^{27}$ Therefore, she asserts, we can be held responsible for things that are not only unintentional but also beyond our control; she refers to this more capacious conception of agency as "non-sovereign agency" and all the obligations that flow from it as "responsibility as accountability." 28 For instance, think about a suitably modified version of the Acquiescence example, where the white candidate accepts the job in total ignorance of the role that race played - not because of a lack of due diligence on the candidate's part, let us say, but because the racist committee member did not publicly state his reasons. The candidate in this case is accountable in Krause's wide sense: although he did 
not intend to play a causal role in maintaining the system of white privilege and, given his ignorance, was powerless to avoid it, he nevertheless has "an obligation to remediate the harms [he has] helped to generate" if they should ever come to light, perhaps by engaging in (additional, special) antiracist political activity. ${ }^{29}$

The first thing to notice about this application of Krause's conception of accountability is the way it turns the agential spotlight away from the racist committee member, who is, after all, the perpetrator of a crime, toward his blameless beneficiary - and blameless, I want to point out, even according to Krause's own account. ${ }^{30}$ Rather than focusing attention on agency that is genuinely evil and truly agential, it unhelpfully shifts it toward "agency" that is blameless and only dubiously agential to begin with, lacking both intent and capacity for control. My worry here is that by trying to expand responsibility in this way, we end up diluting it, leaving a "watery sort" of responsibility, as Aristotle might have put it. $^{31}$

The second thing to notice about it is how it reveals that Krausean accountability does not so much fall prey to the reductio as embrace it with gusto. If responsibility can be triggered-and obligations imposed-by a non-sovereign agency stripped of intentionality and capacity for control, then we are once again trapped in a dense thicket of duties not in any meaningful way of our own making, with our sovereign agency basically reduced to balancing and seeking the means to fulfill these manifold unchosen moral obligations. In fact, when we reflect upon how common situations like the modified version of Acquiescence no doubt are-extending beyond the employment realm to those of religion, hobbies, friendship, romance-the thicket just gets denser and more confining. Though both Krause and Sandel may gaze benignly upon such a prospect, no one who values an even minimally voluntaristic mode of agency should do so. ${ }^{32}$

This being said, I think dismissing Krausean accountability too quickly would be a mistake. Although I doubt that the non-sovereign agency underwriting it is substantial enough to impose special duties, antiracist or otherwise, it may prove substantial enough to serve as a kind of call to attention, a red flag indicating that deep social structures are at work perverting otherwise blameless actions to buttress existing inequalities, including racial ones. Instead of being a sign that blameless actors are under special duties, Krausean accountability should be taken as a signal that our general duties are best directed in a certain way, toward mitigating specific structural inequalities. Understood in this (admittedly deflationary) sense, it can serve important moral purposes without undermining our traditional understanding of responsibility in objectionable ways.

\section{Objection 2: White Wages as the Fruits of Illicit Acts}

I hinted earlier that the undeserved benefits of whiteness might have special characteristics that would insulate the wages-of-whiteness thesis from the force of the 
reductio. One feature that distinguishes white wages from, say, the undeserved benefits of supererogation I focused upon in the reductio itself is that they are the fruits of illicit acts, whether illegal or merely unethical (e.g., employment or spousal discrimination, respectively). Intuitively, this would seem to make it more likely, at least, for white wages to impose special duties than for the benefits of supererogation to do so; if this is in fact the case, then perhaps the thesis can be salvaged after all.

To explore this possibility, let us return once again to the Acquiescence example. One way to conceptualize the wrong that has been committed here is to think of the job as a stolen good that has been "fenced" by the racist committee member. (One can think of the job as having been stolen from the minority candidate, the rest of the hiring committee, or both.) The white candidate is then the innocent purchaser, at least in the modified version of Acquiescence. Once conceptualized in this way, does it suggest that the blameless white candidate, by virtue of the fencing, is nonetheless responsible in some way, perhaps even bearing special duties as a consequence? Not according to European law, at least: so long as the buyer has purchased the fenced item "in good faith" (i.e., in the sincere belief that the seller owns the item) and made reasonable efforts to confirm ownership (due diligence), the thief gives good title-in other words, the buyer owns it free and clear, though the original owner(s) can obviously take legal action against the thief. ${ }^{33}$ American law would usually assign liability to a different party, the buyer, but not in this particular case: the Uniform Commercial Code deems regular dealers in items-and duly authorized hiring committees are analogous to such regular dealers - to give as good or better title than they got, so in this case, the liability lies once again with the dealer (the hiring committee and, more specifically, the racist member), not the innocent purchaser (the blameless white candidate). ${ }^{34}$

Notice two things about this legal analogy. First, unlike Krausean accountability, it keeps the agential spotlight squarely focused on the malefactor (the racist committee member) instead of the innocent recipient (the white candidate) — and this seems intuitively correct. Holding the white candidate responsible under these circumstances appears unreasonable, at least if he has performed due diligence and the hiring committee itself is known as a regular, duly authorized agent. Second, and perhaps contrary to appearances, nothing whatsoever about this analogy rules out affirmative action, racial reparations, or other public-law remedies for structural inequalities. If "fencing" of this kind occurs on a regular basis and tends to disadvantage a particular segment of the population, then public policies to correct this structural inequality might be permitted, even required, and we might all have natural and/or civic duties to support these policies. What the analogy does rule out is holding the blameless recipients of white wages responsible for them and consequently imposing special duties upon them.

Surely, though, a shadow of wrongness still falls across the white candidate and his receipt of the job, suggesting that he bears some kind of responsibility, 
ethical if not legal? I doubt it, due to the fact that the legal analogy is, in a certain way, deceptive. After all, stolen goods can, at least in principle, be tracked across time with enough investigation and returned to their rightful owners. Employment discrimination of the kind imagined in the modified version of Acquiescence is very different, at least in the vast majority of cases: how would we usually even know whether the good in question was being "fenced" at all? Racist committee members will typically offer race-neutral hiring reasons for public consumption, laundering their malign purpose via committee deliberation and voting. ${ }^{35}$ Again, this fact provides evidence for why white privilege is considered unavoidably structural by the philosophy-of-race literature ${ }^{36}$ But if that is the case, then holding the white candidate responsible in any (special) way seems even more unreasonable.

I want to close by bringing this discussion full circle, returning to the Speech of the Laws in Plato's Crito. The Laws at one point inform Socrates that "we have... given you and your fellow-citizens a share in all the good things at our disposal." ${ }^{37}$ And what is the source of all those "good things"? At least in part, Athenian slavery and imperialism - classic(al) examples of stolen goods. Insofar as I am aware, this unfortunate fact has never affected anyone's assessment of the Speech of the Laws ... and rightly so, according to my previous analysis. Socrates is not really responsible for either the benefits he received or the injustices that made them possible until he decides, as an adult, to stay in Athens (no exit) and attempt to persuade (voice). Once his will is engaged in this way, however, he becomes obligated by the benefits and complicit in those injustices. Absent such will implication, he would avoid both obligation and complicity-apart, of course, from the obligation and complicity that flow from our natural duties, from our humanity.

\section{CONCLUSION: NO WHITE DUTIES, NO WHITE GUILT}

Human history, and American history in particular, has been a long story of racial injustice, of racial oppression and exclusion and the continuing fortification of deep structural inequalities. As human beings and Americans, we are obligated to do our part to correct these injustices through political action. Given our common humanity and shared citizenship, we are complicit in all these racial crimes, past and present, regardless of our more particular moral liability, regardless of the alleged purity of our wills. We should feel shame about our history. That something as intrinsically trivial as the accident of skin could yield such a monstrous body count is a judgment on our nation and species.

As this paper has demonstrated, however, all this can be true without it also being true that whites are under special antiracist duties merely on the basis of the undeserved wages of whiteness. For all those whites who affirm their white identity, special antiracist duties and distinctively white guilt are superadded 
to their existing moral liability — and may they eventually find the wisdom to recognize this. For those whites who reject white identity and, indeed, all forms of racial identity as atavistic and depraved, on the other hand, there is no need to feel white guilt: our species guilt and national guilt are a sufficient burden. We should also recognize that the political solidarity that is essential to eliminating white privilege cannot be built on a foundation of white moral debt. This claim would be true — and obviously so — even if the argument of this paper were false. Achieving racial justice requires us to model the very political equality we seek, and that can only be done on the basis not of the superficial things that divide us but rather of those deep things that unite us: our common liberal-democratic citizenship and shared humanity.

University of California, Davis

\section{NOTES}

I thank Jason Brennan and an anonymous referee for their very helpful comments and suggestions.

1. Roediger, Wages of Whiteness.

2. Appiah and Gutmann, Color Conscious, 172-74.

3. Mills, Blackness Visible, 95.

4. Mark Brown, for example, states that white antiracist responsibility is "a matter of holding white people accountable for perpetuating and benefiting from racial injustice, often without intending to or knowing they do" ("James Baldwin," 2-3). Also see Alcoff ("What Should White People Do?" 25); Krause (Freedom, 89-93); Mills ("White Ignorance," 31); Sullivan (Good White People, 5, 129-36; "White Privilege," 335).

5. Appiah and Gutmann, Color Conscious, 173.

6. Mills, Blackness Visible, 95.

7. Rawls, Theory, 197-99.

8. Plato, Crito, 85-92 (50a-54d); Grote, Plato, Vol. 1, 303; de Romilly, La loi, 130.

9. Kraut, Socrates and the State, chaps. 1-6; Kirkpatrick, "Exit out of Athens?"

10. For example, Irwin ("Socratic Inquiry"); and Ober (Athenian Legacies, chap. 7).

11. Plato, Crito, 87 (50d-e).

12. Plato, Crito, 88 (52a).

13. Plato, Crito, 54 (31a).

14. Ober, Athenian Legacies, 160, 166.

15. For example, Kirkpatrick ("Exit out of Athens?” 363); and Whelan (“Citizenship," $639,644)$. 
16. Plato, Crito, 61-62 (36d), 89 (52b-c).

17. Plato, Crito, 88 (51d). At the age of 17, Athenian men went through an involved legal procedure (called dokimasia) that made them citizens; the procedure was predominantly one of civic education and testing. (See Kraut, Socrates and the State, 154.) Therefore, upon becoming adults, citizens were fully aware of the nature of their city and its Laws. I should also note that the process of oath-taking that followed successful dokimasia could be considered explicit consent to the Athenian Laws-though see Klosko ("Oaths") for a contrary view.

18. Plato, Crito, 89 (52e-53a).

19. Note that if there were, say, an epidemic in East Germany at the time, natural duties to relieve suffering might have required them to stay, at least temporarily. (I will say more about such duties shortly.) Also note that the reader is free to substitute a less extreme regime- - I am not trying to rig the example — so long as it also allows no exit or voice.

20. See, for example, Oberman ("Can Brain Drain").

21. Some scholars, like Gutmann (see my opening quotation from her), might argue that the principle of fairness implies that received benefits can impose obligations simpliciter. Rawls, whom Gutmann seems to be silently invoking, would disagree, though: he says that the obligations associated with the principle of fairness assume that "one has voluntarily accepted the benefits of the arrangement," so some unspecified degree of will-implication seems to be required (Rawls, Theory, 96). Thus, Rawls rejects the idea that benefits can unilaterally obligate their recipients on grounds of fairness.

22. Sandel, Liberalism, 152.

23. Krasnoff, "Voluntarism," 48.

24. Sullivan, "White Privilege."

25. I am serious about the friends and spouses: for a moral defense of racial nondiscrimination in personal relationships, see Bedi (Private Racism).

26. I set aside the issue of whether they ought to be allowed to adopt a road in this way. As I noted in the introduction, I am bracketing questions about our natural and civic antiracist duties (viz., their demandingness and content), but it is possible that we have strong natural and civic duties to stop such adoptions by amending adopt-a-road laws to prohibit the participation of hate groups like the KKK - though such an exclusion may raise constitutional questions, of course.

27. Krause, Freedom, 83.

28. Krause, Freedom, 89-91.

29. Krause, Freedom, 89.

30. Krause, Freedom, 89.

31. Aristotle, Politics, 47.

32. Krause herself draws a connection between non-sovereign agency and the writings of Sandel (Freedom, 26n15).

33. Cooter and Ulen, Law and Economics, 141. 
34. Cooter and Ulen, Law and Economics, 141n20. Boonin (Should Race Matter? 29-30) comes to the opposite conclusion by using a similar example-but one that is only superficially so. In his example, the fence is a "shadowy figure" who steals a painting and loans it to a gallery that makes money by displaying it, but such a fence would not be considered a regular dealer by the Uniform Commercial Code, unlike our hiring committee.

35. Interestingly, the Uniform Commercial Code makes a second exception to its typical caveat emptor rule-when the good in question is cash-for obvious reasons: How could a recipient possibly verify whether that money was in fact stolen? (Cooter and Ulen, Law and Economics, 141n20)

36. Sullivan, "White Privilege."

37. Plato, Crito, 88 (51c-d).

\section{REFERENCES}

Alcoff, Linda Martín. "What Should White People Do?" Hypatia 13, no. 3 (1998): 6-26. Appiah, Kwame Anthony, and Amy Gutmann. Color Conscious: The Political Morality of Race. Princeton, NJ: Princeton University Press, 1996.

Aristotle. The Politics. Translated and edited by Ernest Barker. Oxford, UK: Oxford University Press, 1962.

Bedi, Sonu. Private Racism. Cambridge, UK: Cambridge University Press, 2019.

Boonin, David. Should Race Matter? Unusual Answers to the Usual Questions. Cambridge,

UK: Cambridge University Press, 2011.

Brown, Mark. "James Baldwin and the Politics of White Identity." Contemporary Political

Theory 20, no. 1 (2020): 1-22.

Cooter, Robert, and Thomas Ulen. Law and Economics. 3rd ed. Reading, MA: AddisonWesley, 2000.

de Romilly, Jacqueline. La loi dans la pensée grecque: Des origines à Aristote, Collection d'études anciennes. Paris: Les Belles lettres, 1971.

Grote, George. Plato, and the Other Companions of Sokrates. 3 vols. London: J. Murray, 1865.

Irwin, T. H. "Socratic Inquiry and Politics." Ethics 96, no. 2 (1986): 400-15.

Kirkpatrick, Jennet. "Exit out of Athens? Migration and Obligation in Plato's Crito." Political Theory 43, no. 3 (2015): 356-79.

Klosko, George. "Oaths and Political Obligation in Ancient Greece.” History of Political Thought 41, no. 1 (2020): 1-15.

Krasnoff, Larry. "Voluntarism and Conventionalism in Hobbes and Kant." Hobbes Studies 25, no. 1 (2012): 43-65.

Krause, Sharon. Freedom Beyond Sovereignty: Reconstructing Liberal Individualism. Chicago: University of Chicago Press, 2015.

Kraut, Richard. Socrates and the State. Princeton, NJ: Princeton University Press, 1984. Mills, Charles. Blackness Visible: Essays on Philosophy and Race. Ithaca, NY: Cornell University Press, 2015.

. "White Ignorance." In Race and Epistemologies of Ignorance, edited by Shannon Sullivan and Nancy Tuana, 13-38. Albany: State University of New York Press, 2007. 
Ober, Josiah. Athenian Legacies: Essays on the Politics of Going On Together. Princeton, NJ: Princeton University Press, 2005.

Oberman, Kieran. "Can Brain Drain Justify Immigration Restrictions?" Ethics 123, no. 3 (2013): 427-55.

Plato. The Last Days of Socrates: Euthyphro, Apology, Crito, Phaedo. Translated and edited by Hugh Tredennick and Harold Tarrant. New York: Penguin, 1993.

Rawls, John. A Theory of Justice. Rev. ed. Cambridge, MA: Harvard University Press, 1999.

Roediger, David. The Wages of Whiteness: Race and the Making of the American Working Class. New York: Verso Books, 2007.

Sandel, Michael. Liberalism and the Limits of Justice. Cambridge, UK: Cambridge University Press, 1982.

Sullivan, Shannon. Good White People: The Problem with Middle-Class White Anti-Racism. Albany: State University of New York Press, 2014.

"White Privilege." In The Oxford Handbook of Philosophy and Race, edited by Naomi Zack, 331-41. Oxford, UK: Oxford University Press, 2017.

Whelan, Frederick. "Citizenship and the Right to Leave." American Political Science Review 75, no. 3 (1981): 636-53. 